\title{
グリコカリクスが関与する血管内腔の抗血 栓性とその障害
}

射場敏明*

\section{Glycocalyx regulates the intravascular hemostasis}

Toshiaki IBA

要約：近年，血管内皮上に存在するグリコカリクス (glycocalyx)の役割が注 目されている. プロテオグリカン (proteoglycan)やグリコプロテイン (glycoprotein)，糖鎖などからなるこの構造は，血管内腔の血液凝固を抑制してい るだけではなく，血小板や好中球の血管内腔への接着を制御したり，血管透 過性を調節したり，ずり応力などの力学的刺激を感知するなど，多彩な機能 を担っていることが明らかにされてきた，極めて繊細かつ趾弱なグリコカリ クスの研究は, 技術的課題もあってこれまで十分な進展がみられなかった. しかし最近になって検査手法の進歩にともない，ようやく新しい展開がみら れるようになってきた。そしてグリコカリクスは敗血症や虚血再灌流障害と いった急性疾患のみならず, 糖尿病や動脈硬化などの慢性疾患においても, 病態形成においても重要な役割を演じていることが明らかにされた，本稿で はグリコカリクスの構造や機能，疾病との関連などについて最近の知見を紹 介する

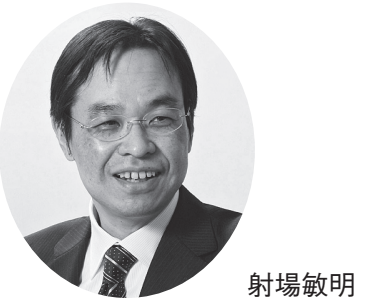

1984 (S59) 年3月 順天堂大学医 学部卒業

1987 (S62) 年4月 順天堂大学医 学部外科学第二講座 助手 1989 ( $\mathrm{H}$ 元年) 6 月 千葉大学医学 部救急部集中治療部 専攻生 1989 ( $\mathrm{H}$ 元年) 9 月 エール大学血 管外科 客員研究員

$1997(H 9)$ 年11月 順天堂大学医 学部外科学第二講座 講師

2006 (H18) 年11月 順天堂大学 医学部救急災害医学研究室 助教授

2007 (H19) 年12月 順天堂大学 医学部救急災害医学研究室 教授

Key words: glycocalyx, syndecan, glycosaminoglycan, heparin sulfate, antithrombin

\section{1. グリコカリクスの構造と機能}

血管内皮細胞の表面にはグリコカリクス (glycocalyx）とよばれる構造体が存在しており，血栓形成や 炎症反応を調節している ${ }^{1)}$ ，グリコカリクスはプロテ オグリカン (proteoglycan) やグリコプロテイン (glycoprotein) などの膜結合部分（コアタンパク）に糖鎖 と血漿タンパクが結合する構造や，直接細胞膜には 結合しないヒアルロン酸 (hyaluronan) などの糖鎖構 造で構成されている ${ }^{2}($ 図 1)。電子顕微鏡による観 察では，内皮細胞に密生したヒゲのようにみえるグ リコカリクスは, 極めて踭弱な構造体であり, 内皮

*責任者連絡先 :

順天堂大学救急・災害医学

干 113-8421 東京都文京区本郷 2-1-1

Tel: 03-3813-3111, Fax: 03-3814-5421

E-mail: toshiiba@juntendo.ac.jp
細胞で合成された後に細胞表面に発現し，やがて血 中に剝離するという新陳代謝を繰り返している。グ リコカリクスは内皮細胞表面以外にも，隣接する内 皮細胞との間隙や基底膜側にも存在しているが, こ のうち内皮細胞間は内皮細胞裂 (endothelial cleft, ETC) と呼ばれ，後述するようにこの部位におけるグ リコカリクスの存在が物質の透過性制御に重要な役 割を担っている3).

a. プロテオグリカン

プロテオグリカンにはシンデカン (syndecan)やグ リピカン (glypican)，ビグリカン (biglycan)などの種 類があり，代表的なプロテオグリカンであるシンデ カンは膜貫通型のコアプロテインと, その細胞外ド メインに結合するグリコサミノグリカン (glycosaminoglycan, GAGs) と称される糖鎖構造で構成されて いる. GAGs の代表はへパラン硫酸 (heparin sulfate) とコンドロイチン硫酸 (chondroitin sulfate) で，前者 


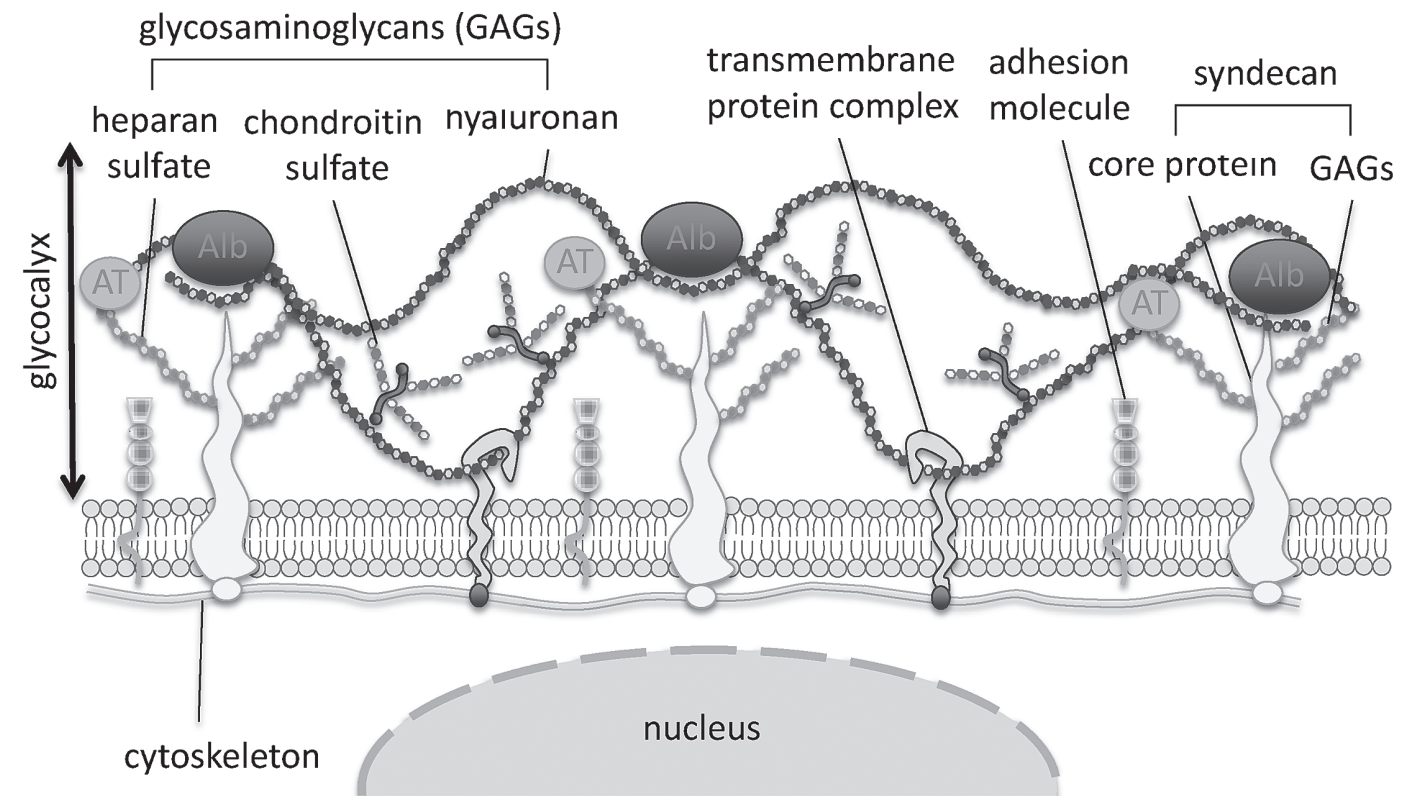

図 1 血管内皮細胞状のグリコカリクス

血管内皮細胞上にはグリコカリクスと総称される構造が存在している。グリコカリクスを構成しているのは細胞膜に固定し たプロテオグリカンと接着分子などのグリコプロテイン，それに細胞膜と直接結合していないヒアルロン酸である。このう ちプロテオグリカンの代表であるシンデカンは，膜を貫通するコアプロテインとこれに結合したへパラン硫酸やコンドロイ チン硫酸など，グリコサミノグリカンと称される糖鎖構造で構成されている。そしてへパラン硫酸にはアンチトロンビンや 成長因子, さらにサイトカイン類などが結合し，それぞれの結合刺激がコアプロテインの細胞質ドメインを介して，内皮細 胞に情報伝達されることが知られている。

AT: antithrombin, Alb: albumin

が 50-90\%を占めている。そしてへパラン硫酸には アンチトロンビンや活性化プロテイン C, tissue factor pathway inhibitor(TFPI) などの凝固制御因子が結 合することが知られており，血管内腔の抗凝固活性 維持に貢献していると考えられる4)。さらに興味深 いことに，グリコカリクスはずり応力や機械的進展 などの物理的刺激の受容体 (メカノセンサー)として も機能し，ストレスファイバーの形成やコラーゲン やフィブロネクチンといった細胞外基質への細胞接 着を調節している。また物理的刺激は，血管内皮か らの nitric oxide $(\mathrm{NO})$ を放出させて血管抵抗を調節し ていることも報告されている3．糖鎖構造のうちへ パラン硫酸は, transforming growth factor- $\beta(\mathrm{TGF}-\beta)$ や vascular endothelial growth factor(VEGF)など, 各 種の成長因子のリガンドとしても機能しており，血 管の再生のみにとどまらず，細胞分化や組織の形態 形成に機能していることが報告されている ${ }^{5)}$.

シンデカンには 1〜4まで, 4 つのサブタイプが 存在することが知られており, 膜貫通構造のうち細
胞外ドメインではそれぞれのシンデカンに3〜9の ヘパラン硫酸，あるいはコンドロイチン硫酸が結合 している。そして細胞質ドメインは, リン酸化やプ ロテインキナーゼ C との結合や活性化を介して, 種々の刺激を細胞内に情報伝達していることが明ら かにされてきた。すなわちシンデカンはサイトカ イン受容体としても機能しており，ヘパラン硫酸に 結合したサイトカインはシンデカンを介して内皮細 胞機能の調節を行っている. Ishiguroらは吕, シン デカン-4ノックアウトマウスは野生型マウスに比 ベてエンドトキシンショックに陥りやすく, 死亡率 も高いことを見いだし，その理由としてノックアウ トマウスではシンデカン-4の欠損により, 野生型 でみられるシンデカン -4 と TGF- $\beta$ の結合による炎 症制御機能が低下していることを挙げている。すな わち TGF- $\beta$ は敗血症の際にみられる IL- $1 \beta$ や TNF $\alpha$ といった炎症性サイトカインの過㮃産生を抑制して いるが, シンデカン-4の減少もしくは久落により TGF- $\beta$ による，このような抑制が働かなくなるとい 
うものである。

\section{b. ヒアルロン酸}

GAGs に絡みつくように存在するコアプロテイン 非結合型高分子ポリマーであるヒアルロン酸は，保 水性に富みアルブミンやフィブリノゲンなどの血漿 タンパクの保持に寄与していると考えられている. 血漿中のアルブミンの保持のメカニズムについては, ETC に存在する㓌性荷電を带びたヒアルロン酸結 合アルブミンが, 同じ荷電状態の血漿中のアルブ ミンと反発することや，GAGsを構成する硫酸基が 同じく陰性帯電しているため, アルブミンと反発し て ETC を通過できないことなどが考えられている. しかし内皮細胞障害に伴って GAGs が剥離すれば, 物理的な間隙の拡大とともに電気的な抵抗もなく なって，アルブミンは容易に血管外に透過していく ことが想定される。このメカニズムについては糸球 体血管内皮細胞を用いた実験で研究されている。そ れによると糸球体血管内皮細胞は直径 50-100 nm の 有空構造を有し, 表面は陰性荷電をもつ GAGsで 覆われ，尿中にアルブミンが逸脱しにくい構造を有 しているとのことである。しかし糖尿病や急性腎障 害 (acute kidney injury, AKI)では, 高血糖や酸化久卜 レスによって GAGs が減少し，それに伴ってアル ブミンが尿中に漏出すようになる。よってこの現象 を利用すれば，尿中の微量アルブミンを測定して尿 中アルブミン/尿中クレアチニン比 (urinary albumin/ creatinine ratio, ACR) を算出することにより，糖尿病 性腎症や急性腎障害の程度を判断することが可能に

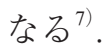

\section{c. グリコプロテイン}

プロテオグリカンとともに細胞膜に直接結合して グリコカリクスを構成するグリコプロテインの代表 はセレクチンやインテグリンなどの接着分子類であ る。これらの発現状態は病態によって様々に変化 し, 白血球や血小板の血管内皮への接着を調節して いる。ここで興味深いのは，接着分子類はプロテオ グリカンょりも長さが短いため, 生理的な状態では プロテオグリカンに被覆されて血球と接触しにくい 構造になっている点である。しかし, 炎症などの刺 激でプロテオグリカンが剝離すると, 血球は露出し た接着分子と直接接触するようになり，内皮細胞に 接着できるようになる(図 2)。言い換えれば白血球
はプロテアーゼや活性酸素を放出してプロテオグリ カンを剝離させることによって着地の地ならしを行 い,引き続いて内皮に接着してさらに障害を進行さ せていくわけである.

\section{2. グリコカリクスの形態と観察}

グリコカリクスは極めて不安定かつ晚弱な構造体 であり，その形態やサイズは観察方法によって報告 ごとに異なっている ${ }^{8)}$.たとえば初期の透過型電顕 による観察では, 厚さ数十 $\mathrm{nm}$ とされていたが, 固 定法を変更して観察を行うと, $5 \mu \mathrm{m}$ 以上の厚みが あるとも報告されている9 。 、いずれにしても電子顕 微鏡下では固定標本の観察しかできず，自然な状態 におけるグリコカリクスの観察は不能である。これ に対し，より生理的な状態におけるグリコカリクス の厚みを推定する方法として, 生体顕微鏡を用いて 赤血球と内皮細胞間の距離を計測することが試みら れた。この手法で測定されたグリコカリクスの厚み は 0.4-0.5 $\mu \mathrm{m}$ ということであり，想定されていたよ りも薄かったことから, 光学顕微鏡における回折空 間分解能の限界が関係していると考えられた。 そこ で上記以外の方法として共焦点レーザースキャンや 2 光子レーザースキャンによる方法など，より洗練 された観察手技が試みられた。その結果, 後者によ る測定ではマウスの頸動脈のグリコカリクスは厚さ $4.5 \mu \mathrm{m}$ ということであったが ${ }^{10)}$ ，同時にグリコカリ クスの厚さは種差や動脈, 静脈, 血管の太さなどに よっては相当に異なることも予想された。 さらにグ リコカリクスの研究を困難にしているのは, 静的な 状態と血流の存在下ではグリコカリクスの発現状態 が全く異なることである11)。たとえばわれわれが培 養内皮細胞に损いて蛍光抗体を用いて行った観察で は, 静的な培養条件下では細胞表面のシンデカンを 検出することできず，またへパラン硫酸などの GAGs を検出することも不能であった，しかし，同 じ培養内皮細胞にヒストンなどの障害因子を加えて 内皮間隙を拡大させると, そこにシンデカン -1 や-4 の発現が観察され, 静的状態でもシンデカンはETC に存在しており, 細胞間接着に機能していることが 想定された(図3)。このような結果から, in vitroの 研究結果をもって生体内のグリコカリクスの状態を 


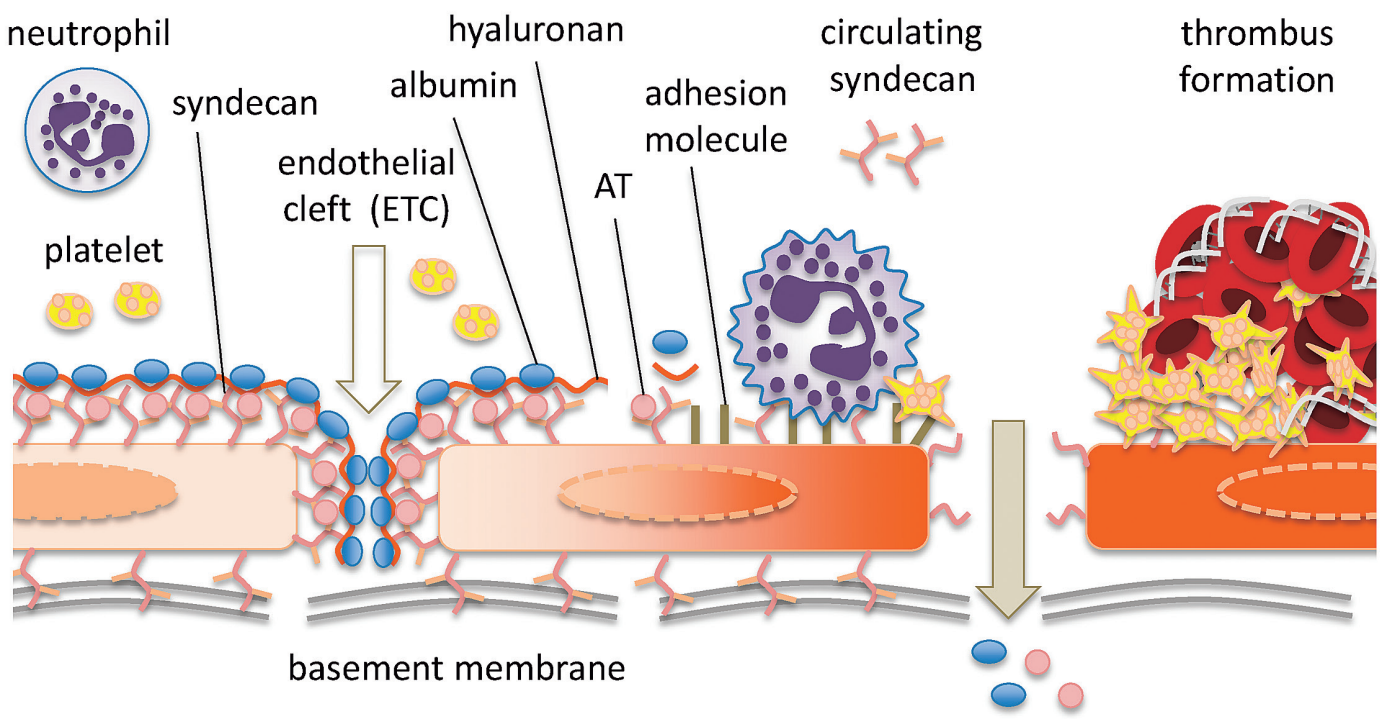

図 2 正常状態と障害時におけるグリコカリクスの発現状態

血管内皮細胞の表面を覆っているグリコカリクスは隣接する内皮細胞との間隙部分である内皮細胞裂 (ETC)にも存在してい る。きわめて䟜弱なグリコカリクスは，種々の炎症性刺激や環境の変化によって容易に剥離して内皮表面には接着分子が露 出し，血球細胞の接着を容易にしている。また ETCにおけるグリコカリクスの障害は血管透過性立進の原因になっている. AT: antithrombin

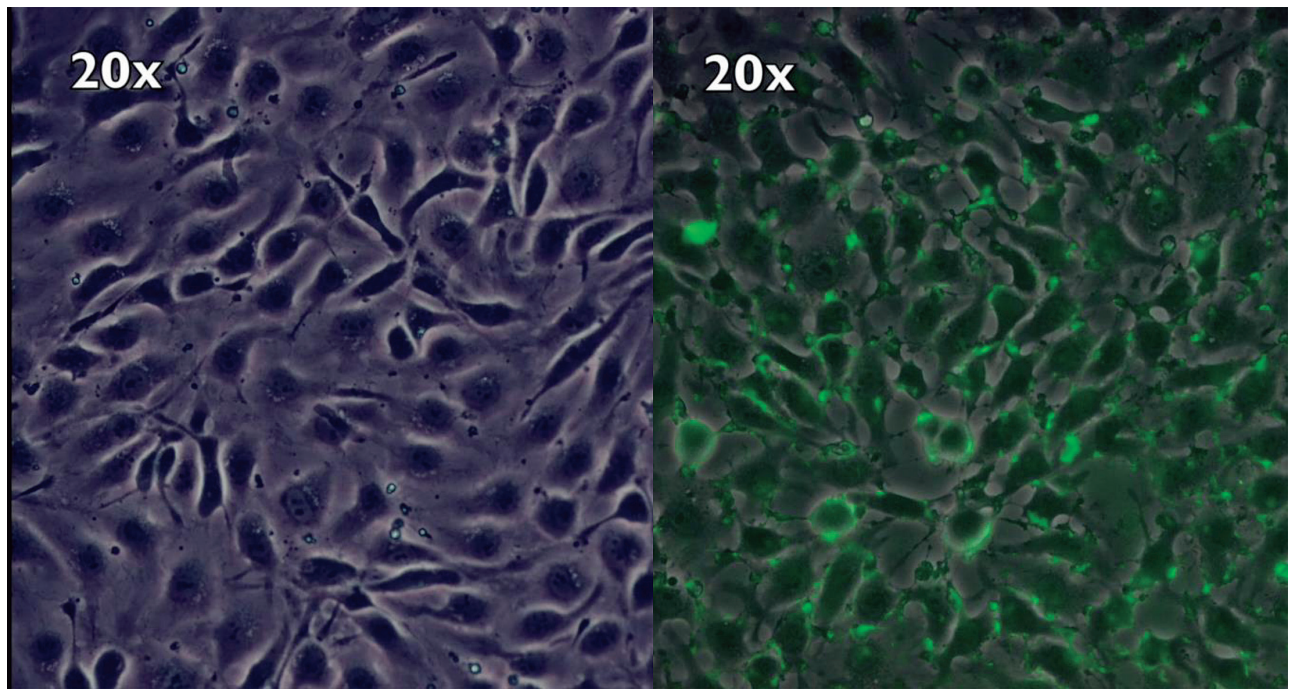

図 3 正常状態と障害時におけるシンデカン -1 の発現状態

正常状態の血管内腔は単層の内皮細胞ですきまなく裏打ちされており，細胞間隙はみられない。静的な状態で培養した血管 内皮ではシンデカン -1 や-4 で蛍光染色を行っても蛍光は認められず，シンデカンの発現はみられない(左)。しかし培養液 中にヒストンを少量加えて内皮細胞に傷害を加え, 細胞間隙が開かれると細胞間に存在するシンデカン -1 が緑色に染色され る。そして培養液中でシンデカン -1 を定量すると，無刺激下では測定限界以下であったシンデカン -1 濃度の増加が確認さ れる。

推定することは困難であると考えられ，このことは 今後この領域の研究を行っていく上で注意が必要な 点である.

\section{3. バイオマーカーとしてのグリコカリクス}

跪弱な構造物であるグリコカリクスは種々の刺激 
で容易に剥離して血中に遊離する。そこで最近で は，このことを利用して血中を循環するグリコカリ クスの各要素を測定することにより, 病態解析や診 断に役立てようとする試みがある。たとえば糖尿病 や動脈硬化などの慢性疾患, そして外傷や敗血症, 虚血再灌流障害などにおける測定結果が報告されて おりバイオマーカーとしての有用性が認知されつつ ある ${ }^{12,13)}$.グリコカリクスが血中に遊離するメカニ ズムとしては, 敗血症においては好中球をはじめと する顆粒球系の細胞はエラスターゼをはじめとする タンパク分解酵素や活性酸素種を放出してコアタン パクを分解し，また形質細胞はへパラナーゼやマト リックスメタロプロテイナーゼによって GAGs を分 離させることが報告されている14)。それ以外にも高 血糖状態ではグリコカリクスの分解が促進され，糖 尿病患者ではグリコカリックス層が菲薄化すること が報告されている ${ }^{15)}$ ，さらに虚血再灌流障害では $\mathrm{pH}$ の変化により分解が促進されることも報告されてい る. そもそもグリコカリクスは, 抗凝固や線溶機能, 血球接着など，血管内皮の重要な機能を担っており， またタンパク質の保持や血管透過性を制御している ことから，血中においてこれらを定量すれば内皮機 能障害を推定できることが期待されている ${ }^{16)}$. 先に 述べたようにシンデカンファミリーには，4つのサ ブタイプが存在する。このうちシンデカン -4 はアン チトロビン結合分子として広く認知されている。そ れぞれのシンデカンは分布に特性があり，たとえば 血管内皮細胞の細胞間や基底膜側にはシンデカン 1，2，4の発現が認められる。 Johanssonらは17)，シン デカン-1 が内皮障害や高濃度のカテコラミン投与 にともなって高值となることを予想し，外傷後の転 帰を予測するマーカーとしての評価を行った。しか しシンデカン-1 は，死亡率の独立した予測因子では あったものの，オッズ比は 1.01[95\%CI：1.00-1.02] であり，その有用性については検討の余地が残ると いう結果であった。一方, Ostrowski らは ${ }^{18)}$, 重症敗 血症 184 例においてシンデカン-1 と thrombelastography $(\mathrm{TEG})$ を測定し，これらが敗血症においてみられ る過凝固状態を反映していることを報告している. またこれとは別に Thorevska らは ${ }^{19)}$ ，ICUに入室し た重症患者 104 人において activated clotting time (ACR) を測定し，69\%に ACRの増加を認めたこと
を報告している。彼らによれば，ACRにより院内 死亡を Acute Physiology and Chronic Health Evaluation II score (APACHE II score) や Sequential Organ Failure Assessment Score (SOFA score) と同程度に予測できる ということである.

\section{4. シンデカンとアンチトロンビン}

生理的な抗凝固物質であるアンチトロンビンに は, 以前から抗凝固作用のみならず抗炎症作用がみ られることが知られていた201. そのメカニズムにつ いては, アンチトロンビンがシンデカン -4 のへパ ラン硫酸に結合することによって, その刺激が血管 内皮細胞におけるプロスタサイクリン ( prostacyclin, $\mathrm{PG} \mathrm{I}_{2}$ ) 産生を促進し, $\mathrm{PG} \mathrm{I}_{2}$ が好中球や血小板の血 管内皮細胞への接着および炎症反応を抑制すると考 えられてきた。アアンチトロンビンについては，ヘパ リンを併用することにより抗炎症効果が減弱するこ とが報告されているが，これについてはアンチト ロンビンのヘパラン硫酸結合部位がヘパリンとの結 合部位と共有であるため，へパリンを併用すると シンデカン -4 への結合が阻害されるためと説明さ れている211.

これとは別にアンチトロンビンによるシンデ カン-4の保護効果が注目されている。マトリプター ゼ (matriptase) は, II 型膜貫通セリンプロテアーゼ ファミリーに属するトリプシン様プロテアーゼで, 基質として細胞外マトリックスや細胞接着分子, 成 長因子様タンパク質，シンデカンなどを分解するこ とが知られているが，内皮細胞表面でシンデカン -4 に結合したアンチトロンビンは，このマトリプター ゼの活性を制御することで，シンデカンの分解・遊 離を抑制することが報告されている22).

著者の利益相反 $(\mathrm{COI})$ の開示：

研究費 (受託研究, 共同研究, 寄付金等) (小野薬品 工業)

\section{文献}

1) Van Teeffelen JW, Brands J, Stroes ES, Vink H: Endothelial glycocalyx: sweet shield of blood vessels. Trends Cardiovasc Med 17: 101-105, 2007.

2) Reitsma S, Slaaf DW, Vink H, van Zandvoort MA, oude Eg- 
brink MG: The endothelial glycocalyx: composition, functions, and visualization. Pflugers Arch 454: 345-359, 2007.

3) Chelazzi C, Villa G, Mancinelli P, De Gaudio AR, Adembri C: Glycocalyx and sepsis-induced alterations in vascular permeability. Crit Care 19: 26, 2015.

4) Nieuwdorp M, Meuwese MC, Vink H, Hoekstra JB, Kastelein JJ, Stroes ES: The endothelial glycocalyx: a potential barrier between health and vascular disease. Curr Opin Lipidol 16: 507-511, 2005.

5) Alexopoulou AN, Multhaupt HA, Couchman JR: Syndecans in wound healing, inflammation and vascular biology. Int $\mathrm{J}$ Biochem Cell Biol 39: 505-528, 2007.

6) Ishiguro K, Kadomatsu K, Kojima T, Muramatsu H, Iwase M, Yoshikai Y, Yanada M, Yamamoto K, Matsushita T, Nishimura M, Kusugami K, Saito H, Muramatsu T: Syndecan-4 deficiency leads to high mortality of lipopolysaccharide-injected mice. J Biol Chem 276: 47483-47488, 2001.

7) Singh A, Satchell SC, Neal CR, McKenzie EA, Tooke JE, Mathieson PW: Glomerular endothelial glycocalyx constitutes a barrier to protein permeability. J Am Soc Nephrol 18: 2885 2893, 2007.

8) Becker BF, Chappell D, Bruegger D, Annecke T, Jacob M: Therapeutic strategies targeting the endothelial glycocalyx: acute deficits, but great potential. Cardiovasc Res 87: 300 $310,2010$.

9) Ebong EE, Macaluso FP, Spray DC, Tarbell JM: Imaging the endothelial glycocalyx in vitro by rapid freezing/freeze substitution transmission electron microscopy. Arterioscler Thromb Vasc Biol 31: 1908-1915, 2011.

10) Vink H, Duling BR: Identification of distinct luminal domains for macromolecules, erythrocytes, and leukocytes within mammalian capillaries. Circ Res 79: 581-589, 1996.

11) Potter DR, Jiang J, Damiano ER: The recovery time course of the endothelial cell glycocalyx in vivo and its implications in vitro. Circ Res 104: 1318-1325, 2009.

12) Henrich M, Gruss M, Weigand MA: Sepsis-induced degradation of endothelial glycocalix. ScientificWorldJournal 10: 917-923, 2010.
13) van Golen RF, van Gulik TM, Heger M: Mechanistic overview of reactive species-induced degradation of the endothelial glycocalyx during hepatic ischemia/reperfusion injury. Free Radic Biol Med 52: 1382-1402, 2012.

14) Becker BF, Jacob M, Leipert S, Salmon AH, Chappell D: Degradation of the endothelial glycocalyx in clinical settings: searching for the sheddases. Br J Clin Pharmacol 80: 389402, 2015.

15) Lopez-Quintero SV, Cancel LM, Pierides A, Antonetti D, Spray DC, Tarbell JM: High glucose attenuates shear-induced changes in endothelial hydraulic conductivity by degrading the glycocalyx. PLoS ONE 8: e78954, 2013.

16) Lennon FE, Singleton PA: Hyaluronan regulation of vascular integrity. Am J Cardiovasc Dis 1: 200-213, 2011.

17) Johansson PI, Stensballe J, Rasmussen LS, Ostrowski SR: A high admission syndecan-1 level, a marker of endothelial glycocalyx degradation, is associated with inflammation, protein C depletion, fibrinolysis, and increased mortality in trauma patients. Ann Surg 254: 194-200, 2011.

18) Ostrowski SR, Haase N, Müller RB, Møller MH, Pott FC, Perner A, Johansson PI: Association between biomarkers of endothelial injury and hypocoagulability in patients with severe sepsis: a prospective study. Crit Care 19: 191, 2015.

19) Thorevska N, Sabahi R, Upadya A, Manthous C, AmoatengAdjepong Y: Microalbuminuria in critically ill medical patients: prevalence, predictors, and prognostic significance. Crit Care Med 31: 1075-1081, 2003.

20) Iba T, Saitoh D: Efficacy of antithrombin in preclinical and clinical applications for sepsis-associated disseminated intravascular coagulation. J Intensive Care 2: 66, 2014.

21) Opal SM, Kessler CM, Roemisch J, Knaub S: Antithrombin, heparin, and heparan sulfate. Crit Care Med 30: S325-331, 2002.

22) Chen YW, Xu Z, Baksh AN, Wang JK, Chen CY, Swanson R, Olson ST, Kataoka H, Johnson MD, Lin CY: Antithrombin regulates matriptase activity involved in plasmin generation, syndecan shedding, and HGF activation in keratinocytes. PLoS One 8: e62826, 2013. 